\title{
ОБЩИЕ ВОПРОСЫ
}

УДК 508.29

\section{1ОЦЕНКА ТРОФИЧЕСКОГО СТАТУСА АГРАХАНСКОГО ЗАЛИВА (СЕВЕРНЫЙ КАСПИЙ) КАК СОСТАВНАЯ ЧАСТЬ ЭКОЛОГИЧЕСКОГО МОНИТОРИНГА ОСОБО ОХРАНЯЕМЫХ ТЕРРИТОРИЙ}

\section{EVALUATION OF TROPHIC STATUS OF AGRAKHAN BAY (THE NORTH CASPIAN SEA) AS A PART OF ECOLOGICAL MONITORING OF SPECIALLY PROTECTED AREAS}

\author{
А.А. Гаджиев ${ }^{1, \text { Г.М. Абдурахманов }}{ }^{1}$, А.М. Дохтукаева", Э.М. Меджидова ${ }^{1}$ \\ A.A. Gadzhiev1, G.M. Abdurakhmanov', A.M. Dokhtukaeva², E.M. Medzhidova1 \\ 'Дагестанский государственный университет, эколого-географический фракультет, \\ ул. Дахадаева, 21, Махачкала, Республика Дагестан 367001 Россия \\ 2Чеченский государственный университет, биолого-химический факультет, \\ ул. Шерипова, 32, Грозный, Чеченская Республика 364907 Россия \\ 'Dagestan State University, ecological and geographical faculty, \\ Dakhadaev str., 21,Makhachkala, Republic of Dagestan 367001 Russia \\ ${ }^{2}$ Chechen State University, faculty of biology and chemistry, \\ Sheripov str., 32, Grozny, Chechen Republic 364907 Russia
}

\begin{abstract}
Резюме. В статье приводятся данные о гидрохимическом составе вод Аграханского залива (Северный Каспий), степени их загрязнения, структуре и количественных характеристиках фитопланктона, зоопланктона и зообентоса. В результате исследований дана оценка трофического статуса залива, определена сезонная трофодинамика. По содержанию растворенного $\mathrm{O}_{2}$ и его биологическому потреблению залив относится к эвтрофным. Однако дефицита кислорода не наблюдается. Концентрация кислорода высокая практически во все сезоны, что благотворно сказывается на жизнедеятельности гидробионтов. Сезонная динамика свидетельствует о том, что Аграханский залив в течение года является олиготрофным, однако наблюдается повышение его трофического статуса к мезотрофному и даже к гипертрофному в отдельные периоды. Северная часть залива является эвтрофной. Такая разница в трофических уровнях указанных частей водоема является следствием существенного различия в глубине и площади поверхности водного зеркала. Негативное антропогенное воздействие на водоем повышает его трофический статус. Сезонный уровень трофрности Аграханского залива, вне зависимости от естественных процессов, зависит от «чистоты» речных наносов Терека, которые являются основными поставщиками биогенных элементов. Как правило, с нарастанием эвтрофикации абсолютная концентрация биогенных элементов возрастает.
\end{abstract}

Abstract. Aim. Hydrochemical composition of waters of Agrakhan Bay (the North Caspian Sea), degree of pollution, structure and quantitative characteristics of phytoplankton, zooplankton and zoobenthos is given in the paper. Evaluation of a trophic status of the bay and seasonal trophodynamics are given as a result of study.

Material and methods. The study is based on original materials from expeditions of 2012 (Autumn) and 2013 (Spring and Summer) in Agrakhan Bay. The complex materials are collected on stations with distance $3.5 \mathrm{~km}$. Totally was made 16 marine stations, where samples of water, phytoplankton, zooplankton and benthos were taken.

Results. Agrakhan Bay is eutrophic by level of dissolved oxygen and its BOD. However, the oxygen deficiency is not observed. concentration of oxygen is high almost in all seasons, that has a beneficial effect on hydrobionts. Seasonal dynamics indicates that Agrakhansky bay is oligotrophic within a year, but its trophic status increases to mesotrophic and even to hypertrophic in some periods. The northern part ща the bay is eutrophic. Difference in trophic levels of different parts of the bay is the result of significant differences in depth and area of water surface.

Conclusions. Anthropogenic impact on Agrakhan Bay increases its trophic status. Seasonal trophic level of Agrakhan Gulf except natural processes depends on the "purity" of the Terek River sediments, which are the main source of biogenic elements. Typically, the absolute concentration of biogenic elements in Agrakhan Bay increases with the increase of eutrophication.

Ключевые слова: Северный Каспий, Аграханский залив, биогенные вещества, содержание кислорода, трофический статус, фитопланктон, зоопланктон, бентос.

Key words: the Northen Caspian Sea, Agrakhan Bay, biogenic elements, oxygen concentration, trophic status, phytoplankton, zooplankton, benthos.

${ }^{1}$ Исследование выполнено при поддержке Министерства образования и науки Российской Федерации, соглашение 14.132.21.1811 «Оценка трофического статуса Аграханского залива как составная часть экологического мониторинга особо охраняемых территорий Дагестана» (с учетом дополнительного соглашения от «18» марта 2013 г. № 1).

The study was supported by The Ministry of Education and Science of Russia, project 14.132.21.1811 (with the additional agreement from 18 March 2013 No 1). 


\section{ВВЕДЕНИЕ}

Антропогенному эвтрофированию океанов, морей, озер, водохранилищ и рек посвящены многочисленные исследования. Участь антропогенного эвтрофирования не миновала и Каспийское море.

Несмотря на то, что Каспийское море является одним из сильно и давно подверженных антропогенным воздействиям водоемов, антропогенному эвтрофированию в нем и связанным с ним вопросам не уделено должное внимание. Однако не вызывает сомнение то, что интенсивное загрязнение водосборной площади и самого моря за последние 50 лет в корне изменило экологическую стабильность Каспия в целом и развитие в нем биоты.

Согласно ГОСТ 17.1.1.01-77 эвтрофирование (эвтрофикация, эвтрофия) вод повышение биологической продуктивности водных объектов в результате накопления в воде биогенных элементов под действием антропогенных или естественных (природных) факторов. Процесс эвтрофирования водоемов неизбежен и закономерен в такой же мере, как старение организмов и их смерть. За время своего существования озеро переходит от стадии водоема с изрезанными берегами, неровным дном, проточной, чистой водой, богатой кислородом и бедной органической жизнью, к стадии зарастающего водоема с пологими берегами, выровненным дном, бурой, богатой органическими веществами водой.

Особо следует подчеркнуть, что между эвтрофированием и загрязнением имеется существенная разница, заключающаяся прежде всего в том, что загрязнение обусловлено сбросом токсичных веществ, подавляющих биологическую продуктивность водоемов, а эвтрофирование в известной степени повышает продуктивность. Антропогенное воздействие нередко сопровождается стрессовыми изменениями озерных экосистем. Эвтрофирование озер под влиянием такого воздействия идет, как правило, иным путем, чем природное, хотя общая схема развития сохраняется. Вот почему выделяется особая область лимнологии - исследование антропогенного эвтрофирования озер, закономерности которого трудно прогнозировать, исходя только из знаний природных процессов эволюции озер.

В этой связи комплексные исследования водоемов, имеющих различный генезис, химический состав, трофический уровень, гидрологический и термический режимы и неодинаковую степень антропогенной нагрузки, весьма актуальны.

Из всех водоемов низовья реки Терек наибольшей освоенностью водосборной площади и степенью антропогенного воздействия отличается Аграханский залив Каспийского моря. В настоящее время облик Аграханского залива заметно изменен. Чтобы понять, что сегодня происходит с Аграханом, необходимо обратиться к его истории. До 1930 года Аграханский залив представлял единый водоем, в северную часть вливались воды реки Терек, в юго-западную часть река Акташ. В результате катастрофических паводков и Каргалинского прорыва основной сток реки Терек стал поступать в Аграханский залив через узкую щель-горловину- Чеканные ворота. Это привело к откладыванию в предустьевой части залива наносов и образованию новых дельтовых притоков и рукавов. Чтобы ослабить паводковый прессинг Терека и избежать окончательного заиливания залива, было принято решение прорыть канал (Прорезь) через Уч-Косу (Аграханский полуостров). И с 1968 года вода Терека начала сбрасываться непосредственно в Каспийское море, минуя залив. Это в итоге привело к полному обособлению частей залива и к резкому осушению северной части залива. Южная часть начала превращаться в замкнутый водоем.

В 1983 году с целью сохранения и восстановления ценных, редких и находящихся под угрозой исчезновения животных и среды их обитания на территории северной части залива создан государственный заказник федерального значения «Аграханский», который в 2009 году приказом Министерства природных ресурсов и экологии России был передан в состав государственного природного заповедника «Дагестанский» в том же статусе. 
Государственный природный заказник федерального значения «Аграханский» имеет профиль биологического (зоологического) и предназначен для сохранения и восстановления ценных в хозяйственном отношении, а также редких и находящихся под угрозой исчезновения объектов животного мира и среды их обитания. Поэтому изучение современного экологического состояния Аграханского залива представляется важным аспектом экологического мониторинга ООПТ Дагестана.

\section{МАТЕРИАЛ И МЕТОДЫ ИССЛЕДОВАНИЯ}

В основу настоящей работы положены собственные материалы, полученные в ходе исследований, проводившихся на территории Аграханского залива. Исследования выполнены при поддержке Министерства образования и науки Российской Федерации, соглашение 14.132.21.1811 (с учетом дополнительного соглашения от 18 марта 2013 г. № 1).

Материал собирался комплексно по установленной сетке с шагом 3,5 км осенью 2012 и весной - летом 2013 года. По всему периметру было 16 станций, на которых выполнялись отбор воды и гидробиологическихпроб фитозоопланктона и бентоса (рис. 1). Координаты станций и краткая характеристика донных отложений приводятся в таблице 1.

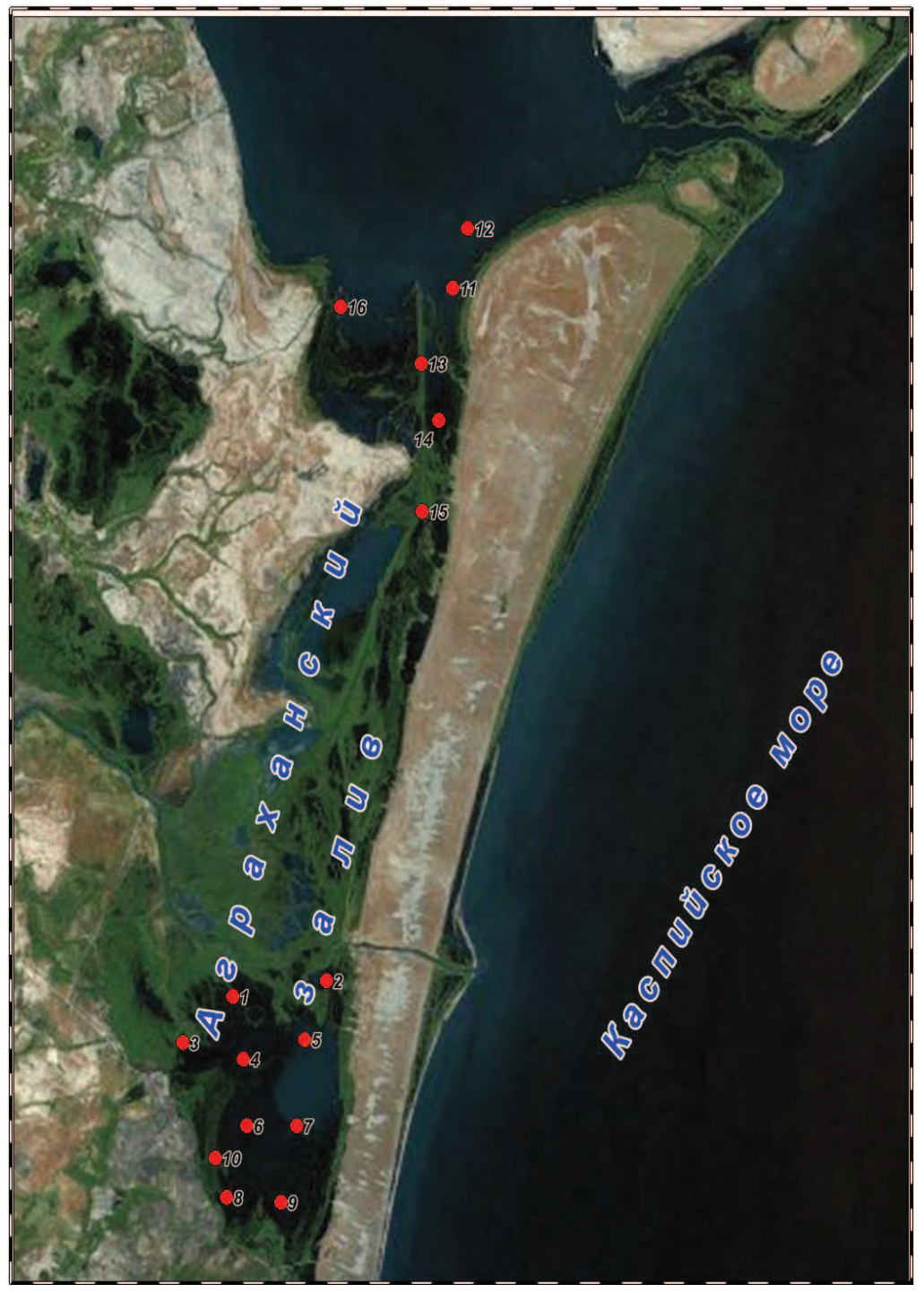

Рис. 1. Карта станций отбора проб 
Материал по фитопланктону собирали с поверхности воды батометром Нансена, по зоопланктону - сетью Апштейна (диаметр входного отверстия 25 см, сито из газа № 38), по бентосу - дночерпателемПетерсена площадью охвата $0,025 \mathrm{~m}^{2}$. Весь биологический материал обрабатывался в лабораторных условиях счетно-весовым методом по общепринятым методикам.

На этих же станциях проводились гидрохимические исследования (pH, прозрачность, температура, растворенный в воде кислород, биогенные вещества и т. д.).

Экспедиционные исследования проводились на базе Передвижной лаборатории экологического мониторинга ДГУ. В ходе выполнения исследований использовались современные физико-химические методы количественного химического анализа, регламентируемые нормативной документацией, утвержденной в установленном порядке для мониторинга и экологического контроля.

Таблииа 1

\section{Координаты станций отбора проб и краткая характеристика донных отложений}

\begin{tabular}{|c|c|c|c|}
\hline \multicolumn{5}{|c|}{ Южная часть залива } \\
\hline № станции & Широта, N & Долгота, $\mathbf{E}$ & Дно \\
\hline $\mathbf{1}$ & $43,35,102$ & $47,24,808$ & ил \\
\hline $\mathbf{2}$ & $43,35,477$ & $47,28,251$ & ил, песок, ракушек мало \\
\hline $\mathbf{3}$ & $43,34,006$ & $47,22,962$ & ил,песок \\
\hline $\mathbf{4}$ & $43,33,598$ & $47,25,182$ & песок, глина, ракушек мало \\
\hline $\mathbf{5}$ & $43,34,059$ & $47,27,427$ & ил, песок, ракушки \\
\hline $\mathbf{6}$ & $43,32,017$ & $47,25,296$ & глина песок \\
\hline $\mathbf{7}$ & $43,32,009$ & $47,27,162$ & глина песок \\
\hline $\mathbf{8}$ & $43,30,299$ & $47,24,562$ & песок, глина \\
\hline $\mathbf{9}$ & $43,30,189$ & $47,26,572$ & глина \\
\hline $\mathbf{1 0}$ & $43,31,238$ & $47,24,147$ & ил \\
\hline \multicolumn{5}{|c|}{ Северная часть залива } & Дно \\
\hline № станции & Широта, N & Долгота, $\mathbf{E}$ & песок, ракушечник, глина \\
\hline $\mathbf{1 1}$ & $43,51,934$ & $47,32,882$ & песок, ракушечник, глина \\
\hline $\mathbf{1 2}$ & $43,53,349$ & $47,33,445$ & глина \\
\hline $\mathbf{1 3}$ & $43,50,150$ & $47,31,717$ & глина, песок \\
\hline $\mathbf{1 4}$ & $43,48,795$ & $47,32,355$ & глина, песок \\
\hline $\mathbf{1 5}$ & $43,46,632$ & $47,31,756$ & глина, песок \\
\hline $\mathbf{1 6}$ & $43,51,482$ & $47,28,769$ & \multicolumn{2}{c}{} \\
\hline
\end{tabular}

\section{РЕЗУЛЬТАТЫ И ОБСУЖДЕНИЕ}

В результате проведенных экспедиционных и лабораторных исследований получен большой объем данных о гидрохимическом составе вод Аграханского залива и о степени их загрязнения, о фитозоопланктоне, бентосных организмах, который был систематизировани обработан.

В гидрологическом и гидрохимическом отношении обе части залива отличаются крайне неустойчивым солевым режимом по сезонам (табл. 2 и 3). За период исследований температура воды здесь колебалась в пределах $17,4-26,8{ }^{\circ} \mathrm{C}$. Соленость в северной части варьировала от 0,7 до 9,1 \%, в южной - от 0,5 до 3,3 \%. В южной части грунты преимущественно илистые и илисто-песчаные, в северной - песчаные, глинисто-песчаные.

Оценка состояния водоема по эколого-санитарным показателям представляет собой сумму гидрофизических и гидрохимических показателей качества вод. По содержанию различных форм азота (аммонийного, нитратного, нитритного) и фосфатов качество вод в заливе варьировалось от «чистого» до «умеренно грязного». 
По данным таблиц 2 и 3 , в период наблюдений из минеральных форм азота большая часть приходилась на нитрат-ионы. Как правило, с нарастанием эвтрофикации абсолютная концентрация нитратного азота и его доля в сумме минерального азота возрастают. Его содержание изменялось в пределах 0,33-9,5 мг/л. Концентрации нитритов как наиболее нестойких соединений процесса нитрификации в период исследований колебались в интервале $0-0,54$ мг/л. Анализы проб весенних съемок в южной части показывают, что в точке отбора проб 1 превышение нитритов составляет 6,75 ПДК, в точке $3-5,37$ ПДК, в точке $8-4,37$ ПДК и в точке $9-1,7$ ПДК. В северной части залива также отмечается превышение допустимых значений нитритов почти на всех станциях наблюдения в весенний период. В воде исследуемого района концентрации иона аммония были невысокими, изменялись в пределах 0-0,159 мг/л, что не выходит за пределы ПДКрх.

Результаты гидрохимических анализов проб воды

Таблий 2 в южной части Аграханского залива

\begin{tabular}{|c|c|c|c|c|c|c|c|c|c|c|}
\hline \multirow{2}{*}{$\begin{array}{c}\text { Показатель } \\
\text { (мг/л) }\end{array}$} & \multicolumn{10}{|c|}{ Станции } \\
\hline & 1 & 2 & 3 & 4 & 5 & 6 & 7 & 8 & 9 & 10 \\
\hline \multicolumn{11}{|c|}{ Осенние съемки } \\
\hline $\mathrm{t},{ }^{\circ} \mathrm{C}$ & 18,2 & 18,3 & 17,4 & 18,1 & 18,2 & 18,1 & 18,3 & 18,2 & 18,3 & 18,5 \\
\hline $\mathrm{pH}$ & 8,0 & 8,2 & 8,1 & 8,2 & 8,0 & 8,1 & 8,0 & 8,0 & 8,0 & 7,7 \\
\hline $\mathrm{HCO}_{3}$ & 134 & 165 & 159 & 171 & 171 & 140 & 159 & 159 & 165 & 244 \\
\hline $\mathrm{Ca}^{2+}$ & 76 & 90 & 80 & 88 & 88 & 72 & 84 & 88 & 84 & 156 \\
\hline $\mathrm{Mg}^{2+}$ & 44 & 49 & 47 & 48 & 48 & 43 & 46 & 55 & 49 & 160 \\
\hline $\mathrm{Cl}^{-}$ & 78 & 87 & 76 & 85 & 85 & 71 & 78 & 99 & 85 & 362 \\
\hline $\mathrm{SO}_{4}^{2-}$ & 420 & 460 & 400 & 460 & 450 & 420 & 430 & 470 & 450 & 1680 \\
\hline $\mathrm{Na}^{+}+\mathrm{K}^{+}$ & 140 & 150 & 130 & 158 & 154 & 146 & 145 & 157 & 154 & 700 \\
\hline $\begin{array}{l}\text { Жест.воды } \\
\left(\text { мг-экв/дм }{ }^{3}\right)\end{array}$ & 7,5 & 8,6 & 7,9 & 8,4 & 8,4 & 7,2 & 8,0 & 9,0 & 8,3 & 21,2 \\
\hline $\begin{array}{c}\text { Сухой } \\
\text { остаток } \\
\end{array}$ & 890 & 1010 & 885 & 1010 & 996 & 890 & 943 & 1030 & 990 & 3300 \\
\hline Взвеш. в-ва & 40 & 180 & 220 & 70 & 320 & 40 & 240 & 40 & 50 & 30 \\
\hline $\mathrm{O}_{2}$ & 10,6 & 11,2 & 9,0 & 11,2 & 10,9 & 11,5 & 9,6 & 11,8 & 11,2 & 4,6 \\
\hline БПК & 1,9 & 2,0 & 1,9 & 2,0 & 2,1 & 1,4 & 1,6 & 1,4 & 1,3 & 3,9 \\
\hline ХПК & 0 & 0 & 13 & 0 & 0 & 0 & 0 & 0 & 0 & 26 \\
\hline $\mathrm{PO}_{4}{ }^{3-}$ & 0,02 & 0,03 & 0,03 & 0,02 & 0,03 & 0 & 0,01 & 0 & 0 & 0,04 \\
\hline $\mathrm{NO}_{4}^{+}$ & 0,099 & 0,023 & 0,035 & 0,051 & 0,030 & 0,012 & 0,079 & 0,048 & 0,150 & 0,105 \\
\hline $\mathrm{NO}_{2}^{-}$ & 0,016 & 0,029 & 0,040 & 0,021 & 0,012 & 0,016 & 0,010 & 0,021 & 0,025 & 0,017 \\
\hline $\mathrm{NO}_{3}^{-}$ & 0,33 & 0,60 & 1,00 & 0,40 & 2,13 & 0,53 & 1,44 & 0,91 & 0,76 & 0,91 \\
\hline \multicolumn{11}{|c|}{ Весенние съемки } \\
\hline $\mathrm{t},{ }^{\circ} \mathrm{C}$ & 18 & 17,6 & 18,1 & 18,3 & 18,1 & 17,9 & 18,4 & 18,1 & 18 & 17,9 \\
\hline $\mathrm{pH}$ & 8,1 & 7,4 & 8 & 8,3 & 8,2 & 8,3 & 8,3 & 8,1 & 8,3 & 7,1 \\
\hline $\mathrm{HCO}_{3}$ & 214 & 232 & 262 & 189 & 214 & 171 & 201 & 177 & 189 & 201 \\
\hline $\mathrm{Ca}^{2+}$ & 120 & 84 & 150 & 116 & 120 & 100 & 118 & 100 & 110 & 108 \\
\hline $\mathrm{Mg}^{2+}$ & 82 & 17 & 74 & 83 & 84 & 89 & 82 & 76 & 78 & 77 \\
\hline $\mathrm{Cl}^{-}$ & 195 & 28 & 160 & 195 & 153 & 156 & 160 & 156 & 156 & 156 \\
\hline $\mathrm{SO}_{4}^{2-}$ & 549 & 125 & 528 & 564 & 571 & 560 & 554 & 491 & 543 & 502 \\
\hline $\mathrm{Na}^{+}+\mathrm{K}^{+}$ & 176 & 37 & 140 & 176 & 154 & 149 & 153 & 143 & 157 & 146 \\
\hline $\begin{array}{l}\text { Жест. воды } \\
\left(\text { мг-экв/дм }{ }^{3}\right)\end{array}$ & 12,8 & 5,6 & 13,7 & 12,7 & 13 & 12,4 & 12,7 & 11,3 & 12 & 11,8 \\
\hline Сухой остаток & 1335 & 523 & 1315 & 1323 & 1295 & 1225 & 1267 & 1143 & 1233 & 1191 \\
\hline Взвеш. в-ва & 88 & 454 & 144 & 90 & 114 & 84 & 116 & 106 & 108 & 110 \\
\hline $\mathrm{O}_{2}$ & 11,1 & 13,2 & 10,7 & 11,1 & 15,6 & 16,0 & 13,6 & 11,2 & 13,6 & 10,7 \\
\hline БПК & 7,1 & 5,1 & 3,6 & 3,1 & 8,7 & 6,5 & 4,9 & 4,9 & 6,9 & 7,9 \\
\hline ХПК & 23,3 & 22,5 & 24,5 & 13,3 & 18,9 & 17,8 & 18,1 & 16,2 & 13 & 15,8 \\
\hline $\mathrm{PO}_{4}^{3-}$ & 0,0056 & $\begin{array}{c}0,005 \\
6\end{array}$ & 0,031 & $\begin{array}{c}0,004 \\
2\end{array}$ & $\begin{array}{c}0,004 \\
2\end{array}$ & $\begin{array}{c}0,005 \\
6\end{array}$ & $\begin{array}{c}0,004 \\
2\end{array}$ & 0,018 & $\begin{array}{c}0,007 \\
0\end{array}$ & 0,022 \\
\hline $\mathrm{NO}_{4}^{+}$ & 0,017 & 0,051 & 0.209 & 0.138 & 0,110 & 0,050 & 0,054 & 0,159 & 0,125 & 0,170 \\
\hline
\end{tabular}




\begin{tabular}{|c|c|c|c|c|c|c|c|c|c|c|}
\hline $\mathrm{NO}_{2}^{-}$ & 0,54 & 0,015 & 0,43 & 0,034 & 0,020 & 0,065 & 0,011 & 0,35 & 0,14 & 0,077 \\
\hline $\mathrm{NO}_{3}{ }^{-}$ & 0 & 9,5 & 2,0 & 0,8 & 0,78 & 0,60 & 1,2 & 0,7 & 0,58 & 0 \\
\hline \multicolumn{10}{|c|}{ Летние съемки } \\
\hline $\mathrm{t}^{\circ} \mathrm{C}$ & 25,9 & 25,5 & 26,1 & 26,3 & 26,2 & 26,5 & 26,4 & 26,7 & 26,8 & 26,1 \\
\hline $\mathrm{pH}$ & 7,7 & 7,8 & 7,8 & 7,9 & 7,8 & 7,6 & 7,9 & 7,8 & 7,8 & 7,8 \\
\hline $\mathrm{HCO}_{3}$ & 183 & 159 & 220 & 256 & 153 & 120 & 140 & 128 & 128 & 140 \\
\hline $\mathrm{Ca}^{2+}$ & 76 & 60 & 100 & 68 & 80 & 80 & 68 & 84 & 86 & 66 \\
\hline $\mathrm{Mg}^{2+}$ & 49 & 16 & 44 & 31 & 28 & 26 & 28 & 53 & 54 & 70 \\
\hline $\mathrm{Cl}^{-}$ & 82 & 32 & 89 & 67 & 67 & 62 & 57 & 92 & 114 & 96 \\
\hline $\mathrm{SO}_{4}{ }^{2-}$ & 290 & 78 & 286 & 240 & 240 & 224 & 208 & 380 & 416 & 400 \\
\hline $\mathrm{Na}^{+}+\mathrm{K}^{+}$ & 79 & 19 & 77 & 117 & 71 & 69 & 58 & 92 & 119 & 97 \\
\hline Жест. воды \\
$($ мг-экв/дм
\end{tabular}

Результаты гидрохимических анализов проб воды в северной части Аграханского залива

\begin{tabular}{|c|c|c|c|c|c|c|}
\hline \multirow{2}{*}{$\begin{array}{c}\text { Показатель } \\
\text { (мг/л) }\end{array}$} & \multicolumn{6}{|c|}{ Станции } \\
\hline & 11 & 12 & 13 & 14 & 15 & 16 \\
\hline \multicolumn{7}{|c|}{ Осенние съемки } \\
\hline $\mathrm{t},{ }^{\circ} \mathrm{C}$ & 17,9 & 18 & 17,9 & 18 & 18,2 & 18,3 \\
\hline $\mathrm{pH}$ & 8,1 & 8,2 & 8,1 & 8,1 & 8,1 & 8,1 \\
\hline $\mathrm{HCO}_{3}$ & 201 & 183 & 214 & 232 & 183 & 201 \\
\hline $\mathrm{Ca}^{2+}$ & 134 & 104 & 114 & 106 & 94 & 66 \\
\hline $\mathrm{Mg}^{2+}$ & 230 & 170 & 130 & 126 & 100 & 31 \\
\hline $\mathrm{Cl}^{-}$ & 1740 & 1350 & 1010 & 920 & 680 & 100 \\
\hline $\mathrm{SO}_{4}^{2-}$ & 1500 & 1140 & 900 & 720 & 500 & 250 \\
\hline $\mathrm{Na}^{+}+\mathrm{K}^{+}$ & 1330 & 1040 & 780 & 670 & 450 & 130 \\
\hline $\begin{array}{l}\text { Жест. воды } \\
\left(\text { мг-экв/дм }{ }^{3}\right)\end{array}$ & 25,8 & 19,7 & 16,9 & 15,8 & 13 & 5,9 \\
\hline Сухой остаток & 5130 & 3990 & 3150 & 2770 & 2000 & 780 \\
\hline Взвеш. в-ва & 0 & 0 & 10 & 10 & 30 & 20 \\
\hline $\mathrm{O}_{2}$ & 13,9 & 13,2 & 11,5 & 12,8 & 11,8 & 12,9 \\
\hline БПК & 2,7 & 2,6 & 3,1 & 2 & 1,8 & 3,2 \\
\hline ХПК & 18,8 & 29,3 & 19,6 & 14 & 10,5 & 5,9 \\
\hline $\mathrm{PO}_{4}^{3-}$ & 0,74 & 0,57 & 0,26 & 0,30 & 0,28 & 3,62 \\
\hline $\mathrm{NO}_{4}^{+}$ & 0,088 & 0,15 & $\mathbf{0 , 1 0}$ & 0,11 & 0,15 & 0,16 \\
\hline $\mathrm{NO}_{2}^{-}$ & 0,038 & 0,034 & 0,008 & 0,015 & 0,021 & 0,018 \\
\hline $\mathrm{NO}_{3}^{-}$ & 1,47 & 1,21 & 0,86 & 0,78 & 0,60 & 1,38 \\
\hline \multicolumn{7}{|c|}{ Весенние съемки } \\
\hline $\mathrm{t},{ }^{\circ} \mathrm{C}$ & 18,1 & 17,8 & 17,9 & 18,6 & 18,4 & 18,7 \\
\hline $\mathrm{pH}$ & 7,6 & 7,9 & 7,5 & 7,3 & 7,4 & 7,6 \\
\hline $\mathrm{HCO}_{3}$ & 214 & 232 & 226 & 256 & 201 & 232 \\
\hline $\mathrm{Ca}^{2+}$ & 260 & 260 & 210 & 240 & 140 & 220 \\
\hline $\mathrm{Mg}^{2+}$ & 492 & 468 & 366 & 420 & 156 & 342 \\
\hline $\mathrm{Cl}^{-}$ & 4083 & 4083 & 3373 & 3905 & 1101 & 3195 \\
\hline $\mathrm{SO}_{4}^{2-}$ & 0,31 & 0,18 & 0,75 & 3,9 & 2,9 & 1,1 \\
\hline
\end{tabular}




\begin{tabular}{|c|c|c|c|c|c|c|}
\hline $\mathrm{Na}^{+}+\mathrm{K}^{+}$ & 2331 & 2309 & 1962 & 2242 & 615 & 1847 \\
\hline $\begin{array}{l}\text { Жест. воды } \\
\left(\text { мг-экв/дм }{ }^{3}\right)\end{array}$ & 54 & 52 & 41 & 47 & 20 & 39,5 \\
\hline Сухой остаток & 9147 & 8963 & 7463 & 8520 & 2811 & 7084 \\
\hline Взвеш. в-ва & 61 & 57 & 57 & 125 & 163 & 85 \\
\hline $\mathrm{O}_{2}$ & 11,5 & 12,8 & 10,7 & 10,7 & 10,9 & 13,5 \\
\hline БПК & 5,1 & 3,9 & 1,5 & 8,3 & 6,1 & 7,5 \\
\hline ХПК & 46 & 42,6 & 33,3 & 19,8 & 26,2 & 4,3 \\
\hline $\mathrm{PO}_{4}^{3-}$ & 0,0042 & 0,0014 & 0,055 & 0,043 & 0,028 & 0 \\
\hline $\mathrm{NO}_{4}^{+}$ & 0,17 & 0,11 & 0,35 & 0,19 & 0,32 & 0,14 \\
\hline $\mathrm{NO}_{2}^{-}$ & 0,19 & 0,25 & 0,20 & 0,42 & 0,085 & 0,024 \\
\hline $\mathrm{NO}_{3}^{-}$ & 0,54 & 0,71 & 0 & 0,63 & 1,2 & 1,1 \\
\hline \multicolumn{7}{|c|}{ Летние съемки } \\
\hline $\mathrm{t},{ }^{\circ} \mathrm{C}$ & 26,5 & 26,4 & 26,1 & 27 & 27 & 27 \\
\hline $\mathrm{pH}$ & 7,7 & 7,6 & 7,7 & 7,7 & 7,9 & 7,6 \\
\hline $\mathrm{HCO}_{3}$ & 220 & 232 & 165 & 177 & 201 & 232 \\
\hline $\mathrm{Ca}^{2+}$ & 200 & 272 & 58 & 58 & 58 & 186 \\
\hline $\mathrm{Mg}^{2+}$ & 389 & 437 & 13 & 18 & 18 & 356 \\
\hline $\mathrm{Cl}^{-}$ & 3550 & 3905 & 39 & 50 & 50 & 2343 \\
\hline $\mathrm{SO}_{4}^{2-}$ & 1144 & 1456 & 78 & 73 & 78 & 1092 \\
\hline $\mathrm{Na}^{+}+\mathrm{K}^{+}$ & 1956 & 2165 & 33 & 33 & 44 & 1232 \\
\hline $\begin{array}{l}\text { Жест. воды } \\
\left(\text { мг-экв/дм }{ }^{3}\right) \\
\end{array}$ & 42,4 & 50 & 4,0 & 4,4 & 4,4 & 39 \\
\hline Сухой остаток & 7460 & 8470 & 386 & 408 & 450 & 5440 \\
\hline Взвеш. в-ва & 73 & 59 & 95 & 54 & 214 & 89 \\
\hline $\mathrm{O}_{2}$ & 10,9 & 9,1 & 9,9 & 4,4 & 14,4 & 10,9 \\
\hline БПК & 2,1 & 0 & 0 & 5,5 & 0,1 & 2,4 \\
\hline ХПК & 90 & 57,2 & 22,8 & 78,8 & 66,6 & 1,8 \\
\hline $\mathrm{PO}_{4}^{3-}$ & 0,016 & 0,0070 & 0,0053 & 0,012 & 0,011 & 0,011 \\
\hline $\mathrm{NO}_{4}^{+}$ & 0 & 0 & 0,050 & 0,071 & 0,058 & 0 \\
\hline $\mathrm{NO}_{2}^{-}$ & 0,017 & 0 & 0,018 & 0,011 & 0,015 & 0,014 \\
\hline $\mathrm{NO}_{3}^{-}$ & 0,31 & 0 & 1,33 & 0,80 & 0,70 & 0,48 \\
\hline
\end{tabular}

Фитопланктон. В летний период в состав фитопланктона залива входило 13 видов водорослей (сине-зеленых -4 вида, диатомовых -4 вида, зеленых - 4 вида, пирофитовых - 1 вид). К наиболее распространенным видам водорослей залива за этот периодотносились Navicula tuscula и Scenedesmus quadricauda.

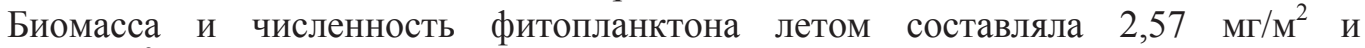
2550 тыс. экз. $/ \mathrm{M}^{3}$ соответственно.

Зоопланктон. В 2013 году летом в южной и севернойчасти залива зарегистрированопо 9-13 видов. Наиболее распространены веслоногие раки из подотряда Cyclopoida и Acartia clause. Из ветвистоусых раков доминировали Chydorus sphaericus и Chydorus avails, Podonevadne camptonyx. Из коловраток наиболее часто встречаются и играют значительную роль в кормовой базе Synchaeta pectinata, Brachionus angularis (табл. 4).

Таблииа 4

Видовой состав зоопланктона северной и южной частей Аграханского залива (лето 2013 года)

\begin{tabular}{|l|c|c|}
\hline \multicolumn{1}{|c|}{ Вид } & Северная часть & Южная часть \\
\hline Copepoda & & - \\
\hline Acartia clausi & + & - \\
\hline Ectinosoma concinnum & + & - \\
\hline Heterocope caspia & + & + \\
\hline Harpacticoida sp. & + & + \\
\hline Calanipeda aquae-dulcis & - & + \\
\hline Megacyclops $(=$ A. ) viridis & - & + \\
\hline
\end{tabular}




\begin{tabular}{|l|c|c|}
\hline Cladocera & & + \\
\hline Daphia pulex & + & + \\
\hline Alona rectangula & + & + \\
\hline Chydorus sphaericus & + & + \\
\hline Chydorus avalis & + & + \\
\hline Bosmina longirostris & + & + \\
\hline Rotatoria & + & + \\
\hline Brachionus angularis & - & + \\
\hline Brachionus plicatilis & + & + \\
\hline Brachionus calyciflorus & + & + \\
\hline Synchaeta longipes & + & $\mathbf{1 3}$ \\
\hline Filina longiseta & $\mathbf{1 3}$ & + \\
\hline Bcero & & + \\
\hline
\end{tabular}

Большинство видов зоопланктона - пресноводные формы, способные переносить значительные колебания солености воды, а также эвригалинные виды, встречающиеся в прибрежной части Каспийского моря.

Биомасса и численность зоопланктона в северной части в летний период состав-

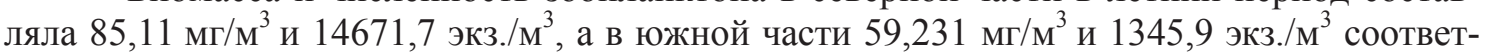
ственно (табл. 5).

\section{Таблица 5}

\section{Численность и биомасса зоопланктона в северной и южной частях Аграханского залива (лето 2013 года)}

\begin{tabular}{|c|c|c|c|c|}
\hline \multirow[t]{2}{*}{ Группы } & \multicolumn{2}{|c|}{ Северная часть } & \multicolumn{2}{|c|}{ Южная часть } \\
\hline & эКз./ $/ \mathbf{M}^{3}$ & $\mathbf{M \Gamma} / \mathbf{M}^{3}$ & экз.// $\mathbf{M}^{3}$ & $\mathbf{M \Gamma} / \mathbf{M}^{3}$ \\
\hline Copepoda & 1580,37 & 36,47 & 293,3 & 4,145 \\
\hline Cladocera & 490,25 & 9,24 & 396,3 & 24,887 \\
\hline Rotatoria & 4670,45 & 26,83 & 396,3 & 2,986 \\
\hline Прочие & 7930,63 & 12,57 & 260 & 27,213 \\
\hline Итого & 14671,7 & 85,11 & 1345,9 & 59,231 \\
\hline
\end{tabular}

Донная фауна. Видовой состав донной фауны северной части богаче (13 видов), чем в южной части (9 видов). В составе донной фауны преобладают пресноводные и солоноватоводные формы. В южной части не встречаются виды морского происхождения, такие как Nereis diversicolor иCerastoderma lamarki (табл. 6). Наиболее характерной и важной в кормовом отношении группой бентоса Аграханского залива являются олигохеты. Они распространены по всему заливу.

\section{Видовой состав бентоса в северной и южной частях Аграханского залива (лето 2013 года)}

\begin{tabular}{|l|c|c|}
\hline \multicolumn{1}{|c|}{ Вид } & Северная часть & Южная часть \\
\hline Черви & & + \\
\hline Hypania invalida & + & - \\
\hline Hypaniolla kowalewskii & + & + \\
\hline Oligochaeta & + & + \\
\hline Nereis diversicolor & + & + \\
\hline Pакообразные & + & - \\
\hline Pontogammarus maeoticus & + & + \\
\hline Pontogammarus robustoides & + & + \\
\hline Pterocuma pectinata & + & + \\
\hline Corophium sp. & & + \\
\hline Моллюски & + & + \\
\hline Dreissena polymorpha & & \\
\hline
\end{tabular}




\begin{tabular}{|l|c|c|}
\hline Hypanis colorata & + & + \\
\hline Teodoxsus pallasi & + & + \\
\hline Cerastoderma lamarki & + & \\
\hline Личинки насекомых & & + \\
\hline Chironomidae Всего: & + & $\mathbf{9}$ \\
\hline \multicolumn{1}{|c|}{ Все } & \\
\hline
\end{tabular}

В северной части залива биомасса бентоса в среднем составляла 1066 мг/м² при численности 227 экз./ $\mathrm{m}^{2}$. В южной части ее количественные показатели были значитель-

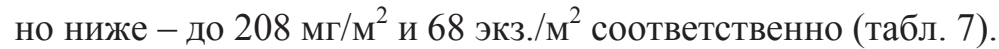

Таблииа 7

\section{Численность и биомасса зоопланктона в северной и южной частях Аграханского залива (лето 2013 года)}

\begin{tabular}{|c|c|c|c|c|}
\hline \multirow[t]{2}{*}{ Группы } & \multicolumn{2}{|c|}{ Северная часть } & \multicolumn{2}{|c|}{ Южная часть } \\
\hline & ЭКЗ./ $/ \mathbf{M}^{3}$ & $\mathbf{M \Gamma} / \mathbf{M}^{3}$ & ЭКЗ./ $/ \mathbf{M}^{3}$ & $\mathbf{M \Gamma} / \mathbf{M}^{3}$ \\
\hline Черви & 100 & 133 & 64 & 108 \\
\hline Ракообразные & 100 & 80 & - & - \\
\hline Моллюски & 7 & 800 & 4 & 100 \\
\hline Всего & 227 & 1066 & 68 & 208 \\
\hline
\end{tabular}

\section{ТРОФИЧЕСКИЙ СТАТУС АГРАХАНСКОГО ЗАЛИВА (ЛЕТО 2013 ГОДа)}

К построению типологической системы водоемов подходят с разных точек зрения.

Так, географы и геологи классифицируют озера на основании особенностей происхождения и структуры озерных ванн. Зоологи главное свое внимание обращают на донную фауну. Ботаники группируют водоемы на основании данных о фитопланктоне, фитобентосе и высшей водной растительности. Ихтиологи исходят из факта доминирования в прудах и озерах тех или иных пород рыб. Имеется много классификаций, выполненных химиками, гидрологами, геофизиками.

В условиях Дагестана в настоящее время нет ни одного водоема, на котором бы одновременно и систематически велись вышеперечисленные комплексные наблюдения за его режимом, а также не проводились специальные исследования для установления типологии озер.

При типологизации водоемов Дагестана мы берем за основу трофность водоемов, которая оценивается по степени степени развития фитозоопланктона и бентосав водоемах, кроме того, учитывались глубина, температура воды, химический состав воды, ихтиофауна, высшая растительность. Водоемы по трофности делятся на основные три типа:

1) высококормные - это эвтрофные озера, в которых биомасса планктона состав-

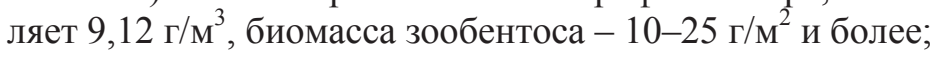

2) среднекормные - это эвтрофные, мезотрофные озера, в которых биомасса

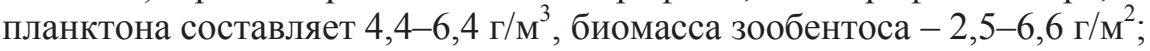

3) малокормные - это олиготрофные, зарастающие, дистрофирующие озера, в ко-

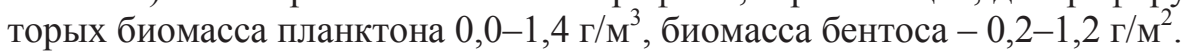

По имеющимся данным по кормовой базе мы попытаемся дать трофическую оценку северной и южной частей Аграханского залива.

Эти водоемы имеют следующие признаки: расположены в равнинной зоне, имеют небольшие глубины, с хорошо выраженной литоралью и богатой растительностью. Их вода прогревается до дна. Грунты илистые, содержат много органического вещества, в придонном слое мало кислорода, зимой иногда наблюдаются заморы. На основании имеющихся данных видового состава, численности и биомассы организмов, обитающих в северной и южной частях Аграханского залива, биомасса планктона составляет 0,09-0,06

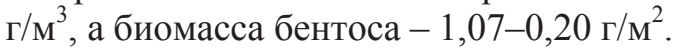


Таким образом, исследованные нами водоемы по биологической квалификации относятся к олиготрофным - малокормным.

По содержанию соединений азота, фосфатов, растворенного кислорода и его биологическим потреблением, перманганатной окисляемости можно судить о сезонной трофодинамики водоема.

Сезонная трофодинамика определялась в соответствии с классификацией водоемов по классам сапробности (табл. 8). Класс ксеносапробности соответствует олиготрофному уровню по трофической классификации водоемов, олиго- и $\beta$ мезосапробности - мезотрофному уровню, $\alpha$-мезосапробность и полисапробность - эвтрофному и гиперсапробность - гипертрофному.

Таблица 8

\section{Классификация водоемов по классам сапробности}

\begin{tabular}{|c|c|c|c|c|c|c|}
\hline \multirow{4}{*}{$\begin{array}{l}\text { Наименование } \\
\text { показателей }\end{array}$} & \multicolumn{2}{|c|}{ Чистые воды } & \multicolumn{2}{|c|}{ Загрязненные воды } & \multicolumn{2}{|c|}{ Грязные воды } \\
\hline & \multicolumn{6}{|c|}{ Классы сапробности } \\
\hline & $\begin{array}{c}\text { Ксено- } \\
\text { сапробность }\end{array}$ & $\begin{array}{c}\text { Олиго- } \\
\text { сапробность }\end{array}$ & $\begin{array}{c}\beta \text {-мезо- } \\
\text { сапробность }\end{array}$ & $\begin{array}{c}\alpha \text {-мезо- } \\
\text { сапробность }\end{array}$ & $\begin{array}{c}\text { Поли- } \\
\text { сапробность }\end{array}$ & $\begin{array}{c}\text { Гипер- } \\
\text { сапробность }\end{array}$ \\
\hline & (кс) & (o) & (бм) & (ам) & (п) & (гп) \\
\hline \multicolumn{7}{|c|}{ Трофо-сапробные показатели } \\
\hline $\begin{array}{l}\text { Растворенный } \\
\text { кислород, } \\
\text { \% насыщения }\end{array}$ & $95-100$ & $80-110$ & $60-125$ & $30-150$ & $0-200$ & 0 \\
\hline БПК $5, \mathrm{мгO}_{2} / л$ & $0-0.5$ & $0.6-1.0$ & $1.1-2.0$ & $2.1-3.0$ & $3.1-10.0$ & Более 10 \\
\hline $\begin{array}{l}\text { Перманганатная } \\
\text { окисляемость } \\
\text { по Кубелю, } \\
\mathrm{MгO}_{2} / \text { / (ХПК) }\end{array}$ & $0-7.0$ & $7.1-10.0$ & $10.1-20.0$ & $20.1-40.0$ & $40.1-80.0$ & Более 80 \\
\hline $\begin{array}{l}\text { Аммоний соле- } \\
\text { вой, мг/л }\end{array}$ & $0-0.05$ & $0.06-0.1$ & $0.11-0.5$ & $0.51-1.0$ & $1.01-3.0$ & Более 3 \\
\hline Нитраты, мг/л & $0.05-5.0$ & $5.1-10.0$ & $10.1-40.0$ & $40.1-80.0$ & $80.1-150.0$ & Более 150 \\
\hline Нитриты, мг/л & $0-0.001$ & $0.002-0.04$ & $0.0-0.08$ & $0.09-1.5$ & $1.6-3.0$ & Более 3 \\
\hline Фосфаты, мг/л & До 0.005 & $0.006-0.03$ & $0.04-0.1$ & $0.11-0.3$ & $0.31-0.6$ & Более 0.6 \\
\hline
\end{tabular}

По содержанию аммонийного азота была получена следующая картина: южная часть залива - мезотрофная, а в летние месяцы - олиготрофная. Северная часть - в осенние и весенние месяцы мезатрофная, летом - олиготрофная.

В результате сравнения данных по содержанию нитритов с таблицей 19 , южную часть водоема можно в осенний период отнести к олигатрофной, в весенний период - к эвтрофной и в летний период - к мезотрофной. Северную часть осенью и весной можно охарактеризовать как мезатрофную, летом как эвтрофную.

Содержание нитратов в пробах оказалось в пределах нормы. По содержанию нитратов Аграханский залив можно отнести к олиготрофным.

По концентрации фосфатов в Аграханском залив можно определить южную часть как олиготрофную, приближающуюся к мезатрофной, северную часть как мезотрофную, а в летние месяцы как гипертрофную.

Кислородный режим является основным показателем, иллюстрирующим процессы, происходящие в водных экосистемах. Поэтому правильная интерпретация может дать важную информацию об их экологическом состоянии. По содержанию растворенного $\mathrm{O}_{2}$ и его биологическому потреблению залив относится к эвтрофным. Однако дефицита кислорода не наблюдается. Концентрация кислорода высокая практически во все сезоны, что благотворно сказывается на жизнедеятельности гидробионтов. По показателю химического потребления кислорода Аграханский залив относится к эвтрофному типу. 
В результате анализа сезонной трофодинамики вытекает следующее: Аграханский залив в течение года в основном олиготрофный, однако наблюдается повышение его трофического статуса к мезатрофному и даже к гипертрофному в отдельные периоды. Северная частьявляется эвтрофной. Такая разница в трофических уровнях указанных частей водоема является следствием существенного различия в глубине и площади поверхности водного зеркала.

Из всего вышесказанного можно сделать обобщающий вывод: чем значительнее негативное антропогенное воздействие на водоем, тем выше его трофический статус. То есть сезонный уровень трофии Аграханского залива, вне зависимости от естественных процессов, зависит от «чистоты» речных наносов Терека, которые являются основными поставщиками биогенных элементов. Как правило, с нарастанием эвтрофикации абсолютная концентрация биогенных элементов возрастает.

\section{БИБЛИОГРАФИЧЕСКИЙ СПИСОК}

Мирзоев М.3. 1984. Рыбохозяйственное значение Аграханского залива в современных условиях. Автореф. дис. ... канд. биол. наук. М. 48 с.

Науменко М.А. 2007. Эвтрофирование озер и водохранилищ. Учебное пособие. СПб.: Изд-во РГГМУ. 100 с.

ГОСТ 17.1.1.01-77. Охрана природы. Гидросфера. Использование и охрана вод. Основные термины и определения (с Изменениями № 1, 2) - введ. 1978-06-30. М.: Государственный комитет СССР по стандартам.

ГОСТ 17.1.5.01-80. Общие требования к отбору проб донных отложений водных объектов для анализа на загрязненность - введ. 1982-01-01. М.: Государственный комитет СССР по стандартам.

\section{REFERENCES}

Mirzoev M.Z. 1984. Rybokhozyaystvennoe znachenie Agrakhanskogo zaliva v sovremennykh usloviyakh [Fishery significance of Agrakhan Bay in present-day conditions. PhD Thesis] Moscow. 48 p. (in Russian).

Naumenko M.A. 2007. Evtrofirovanie ozer i vodokhranilishch. Uchebnoe posobie [Eutrophication of lakes and reservoirs]. Saint Peterburg: RSHU Publ. 100 p. (in Russian).

GOST 17.1.1.01-77. Okhrana prirody. Gidrosfera. Ispol'zovanie i okhrana vod. Osnovnye terminy i opredeleniya (s Izmeneniyami 1,2) - vved. 1978-06-30 [GOST 17.1.1.01-77. Protection of nature. Hydrosphere. Use and protection of water. Basic terms and definitions (Amended N 1,2) - introduced 1978-06-30]. Moscow: State Committee on standards of the USSR (in Russian).

GOST 17.1.5.01-80. Obshchie trebovaniya k otboru prob donnykh otlozheniy vodnykh ob"ektov dlya analiza na zagryaznennost' - vved. 1982-01-01 [GOST 17.1.5.01-80 General requirements for sampling of bottom sediments of water bodies for the analysis of the pollution. - introduced 1982-01-01]. Moscow: State Committee on standards of the USSR (in Russian). 